\title{
Australasian Parliamentary Debate Strategy to Foster Students' Speaking Competence
}

\author{
Ulil Fuadah $^{1}$, Sri Rachmajanti ${ }^{1}$, Fracisca Maria Ivone ${ }^{1}$ \\ ${ }^{1}$ Language Teaching-State University of Malang
}

\begin{tabular}{l}
\hline \hline ARTICLE INFO \\
\hline Article History: \\
Diterima: $31-07-2019$ \\
Disetujui: 13-04-2020 \\
\hline
\end{tabular}

\section{Key Words}

classroom action research; speaking competence; australasian parliamentary debate

\begin{abstract}
Abstract: Teaching English needs an appropriate strategy to effectively enhance the students' communicative competence, especially speaking competence. When the teaching process does not use the appropriate strategy, the students will meet the barriers to achieving the instructional goals. Based on the preliminary study conducted to the second grade of Islamic Senior High School of Blitar, the researcher found some students' speaking problems. Therefore, the Australasian Parliamentary Debate was proposed as a strategy to overcome those problems by conducting Classroom Action Research. After implementing the strategy of Australasian Parliamentary Debate in multimodal teaching-learning process, the study needed two cycles to overcome the students' speaking problems and improve the students' speaking skill.
\end{abstract}

\section{Correspondence Address:}

\begin{abstract}
Abstrak: Mengajar bahasa Inggris membutuhkan strategi yang tepat agar mampu meningkatkan kemampuan siswa dalam kompetensi komunikatifnya, khususnya kompetensi berbicara. Apabila pembelajaran tidak menggunakan strategi yang tepat, maka siswa akan mengalamai kesulitan untuk mencapai tujuan pembelajaran yang diharapkan. Sesuai dengan hasil observasi yang dilakukan di kelas dua MAN Kota Blitar, peneliti menemukan beberapa permasalahan siswa dalam berbicara. Oleh karena itu, peneliti mencoba menerapkan strategi Debat Parlementer Australia untuk mengatasi permasalahan yang dihadapi siswa dalam belajar berbicara. Setelah penerapan strategi tersebut, dengan menekankan pada proses pembelajaran berbasis multimodal, peneliti membutuhkan dua siklus untuk dapat mengatasi permasalahan yang dihadapi siswa dan meningkatkan kemauan berbicara mereka.
\end{abstract}

\section{Ulil Fuadah}

Language Teaching Program of State University of Malang

05 Semarang Street, Malang, East Java

E-mail: fuadahulil@gmail.com

One of the responsibilities of English teachers is devotedly to foster the students' communicative competences, which means to assist the students in being competent communicatively (Sulistyo, 2018). Selecting an effective strategy and implementing the strategy in an appropriate way will indicate that the process of teaching and learning is successful (Chai \& Kong, 2017). According to (Hans, 2017), good teaching and learning in the class are to create a successful learning environment; indeed, having a positive impact on students achievement. The English language has been used universally for all types of communication, and speaking has an important role to make the interaction clear. It is really necessary to be mastered by the learner (Arung, 2016; Jahbel, 2017). However, speaking is not limited with informing the audience or expressing their thoughts publically, but changing emotion, actions and attitude, and leaving the listeners moved by the words and touched by their meaning (Flucher, 2003).

Although speaking is essential to be mastered by students, in fact, the researcher found several problems from the students of senior high school in mastering speaking competence. The researchers found the case at the second grade of Islamic Senior High School of Blitar based on the result of a preliminary study by interviewing the English teacher, giving the questionnaire to the students and conducting a speaking test. The students were still having trouble to construct what they want to say. In details problems, the problems were about vocabularies, grammar, pronunciation, fluency, and anxiety. Furthermore, based on the result of pre-test, asking the students to deliver arguments individually in front of the class, the mean score of students' speaking was very low; the mean score was only 43.3 in the scale level of 1-100.

Besides, the teacher said that the low participation of students in improving English speaking caused this problem as well. Many students were less responsive and infrequently speak English during the learning process. Usually, the teacher warns students to always play an active role in the teaching and learning of English, but all students did not do cooperatively, so the process of teaching-learning is impressed passive process. 
Teaching speaking needs an appropriate strategy that can utterly foster the students' competence and reach the instructional objective. Debate strategy is one of the effective strategies in teaching language (Arung, 2016; Fikri, 2013; Sueb, 2014; Syandiamita, 2011). The debate is the process of inquiry and advocacy, a way of arriving at a reasoned judgment on a proposition. Through debate, students learn how to use the library, to reason, to analyze, to clarify ideas and to present arguments (Alasmari \& Salahuddin Ahmed, 2012; Zare \& Othman, 2013). It will be required for individuals to decide in their minds; they try to subjugate the problem, construct their way of thinking, and promote their critical thinking (Freeley \& Steinberg, 2009; Park, Kier, \& Jugdev, 2011). Many academic debate styles in the world can be applied as the teaching strategy, namely Australasian parliamentary debate, British Parliamentary debate, Asian Parliamentary debate, American Parliamentary debate, so forth.

Australasian Parliamentary Debate (APD) is the most suitable strategy that can be practiced by the students. It has grown in popularity in recent years and may be an appropriate debate for contemporary college students or Millennials. The Australasian Parliamentary Debate strategy is the kind of parliamentary debate under the Australasian Parliamentary rules. The characteristics of this debate are the number of debaters and team in the exhibition. There are two teams, government and opponent. Each team consists of three members who have a different job during the debate.

The similar study has been reported by Arung. He conducted the classroom action research which aimed to improve the students' speaking ability by using the debate strategy. The setting of the study was in the second year of SMA Negeri 1 Lususa with the number of participants were 29 students of class XI/IPA 2. The implementation of this debate strategy in teaching speaking was conducted in two cycles. The result showed that using a debate technique can improve students' speaking skill. Unfortunately, the kind of debate in this study was not specified (Arung, 2016). Furthermore, in the previous study conducted by Suhendra discussed the further contributions of the English debate within the Communicative Language Teaching framework. The chosen English Debate here was specified for parliamentary debate. He stated that by using parliamentary debate, it promoted the students' macro skill of language, such as reading, writing, listening, and speaking. Moreover, it was stated as well that the parliamentary debate strategy promoted the students' critical thinking competence and self-confidence (Suhendra, 2015).

The similarities of this study with the previous studies are the area of study and the teaching-learning strategy that was used in the study, debate strategy. The first study used the debate strategy to overcome the students' speaking problems in the classroom, and the second study tried to analyze the further contributions of debate strategy for the students during learning English. Both of study showed the reader that the debate strategy was applicable for the students to have more capacity in mastering English, especially for speaking competence.

The differences of this study with the previous studies are the setting of the study and the kind of debate strategy used in the study. The first study did not use the specified debate strategy in teaching speaking, but this study used the Australasian Parliamentary Debate strategy which was a more structural and appropriate strategy to be implemented for senior high school students. Whereas, the second study conducted the study under the design of qualitative which it was to analyze the further contributions of parliamentary debate. Besides, the study used the setting of study for undergraduate level.

Seeing the fact that there were still some speaking problems found in Islamic Senior High School of Blitar, and then there was an effective strategy that can be implemented by the teacher to overcome those problems. Therefore, practically researcher conducted the classroom action research to overcome the students' problem in learning speaking by Australasian Parliamentary debate strategy. Theoretically, the result of the study will be valuable in an attempt to elaborate on the potential strategy that using Australasian parliamentary debate can improve ELT students' speaking competence. Finally, this article aimed to show the results of conducting Australasian Parliamentary Debate as an effective strategy to overcome the students' problems in speaking.

\section{METHOD}

The design of this research was classroom action research. Classroom Action Research CAR is a kind of research design conducted in cycles and it is carried out to increase the quality of teaching and learning activities in the classroom (Sukardi, 2013). This study conducted Classroom Action Research by applying Australasian Parliamentary Debate as the strategy to improve the students' speaking. The researcher acted as the English teacher to plan, implement, observe and reflect the students' activities during the process of teaching-learning. The researcher conducted the classroom action research in Islamic Senior High School of Blitar, exactly at the class of XI/IPA-2. The classroom consisted of 31 students and they were as subjects of this research.

The criteria for success were set to see whether the implementation of the modified technique was successful or not. Classroom action research was believed to be successful if it can exceed the criteria which have been determined. The criteria of success were determined not only seeing the students score in the speaking test, but also students' response motivation, behavior, and interest during the process of teaching and learning. The data was collected by observing, questionnaire, testing, and field notes. 
To know students' responses in learning speaking during applying APD, the researcher used collaboration both observation and field note. The researcher assessed the activeness of the students during the process of teaching-learning by observing their motivation, behavior, and interest; it was successful if the students were active and confidence in the process of teaching-learning.

\section{FINDINGS}

Findings on Cycle 1

Regarding the improvement of students speaking ability, the researcher used the modified APD strategy for Cycle 1. The implementation was conducted until three meetings for applying the strategy and one meeting for the speaking test. In the first meeting, the activities were discussing the argumentation text, assuring the students' understanding, simulating, making group, classifying who became debaters and adjudicators, and giving the debate motions to the students and asking them to surf any materials. In the second meeting, the next activities were making the debate battle list and discussing the motions with a different topic. The third meeting, students were asked to continue the discussion for a few minutes then built the APD exhibition in front of the class. The sequences of doing APD were started from the opening section by the teacher. Then, the students deliver the speech. The Speech was preceded by the 1st speaker of affirmative, continued by the 1st speaker of negative, then rebutted by the 2nd speaker of affirmative, then 2nd speaker of negative, added by the 3rd speaker of affirmative, lastly, 3rd speaker of negative. Here was no replier. During the process of APD exhibition Teacher observed and monitored the running of debate and noted any important information regarding the process of learning. And the last, teacher offered adjudicators to adjudicate the debaters' performance. After the process of debate finished, the teacher evaluated the process of students' learning and gave them constructive feedbacks. To know the students' improvement, the speaking test was built for every student. The test was like in the preliminary study.

\section{Students' Speaking Score}

The speaking test was done in a form of APD Exhibition which offering students to at least waste 2 minutes in delivering arguments and if needed. By setting the passing score, the students had to achieve a minimum score of 70 . The result has shown that the strategy has improved the students' speaking competence in the speaking test in Cycle 1. In the preliminary study, the researcher found the mean score of speaking test was 43.9, after conducting the strategy by APD students reached up to 68 , by 50 as the lowest score and 87 as the highest score. Considering the minimum score, $\geq 70$, there were about 13 students or $42 \%$ of students could not meet score $\geq 70$.

\section{Students' Responses}

By giving the modified strategy of Australasian Parliamentary Debate, the teacher forced them and controlled over every student to be active in every activity. The activities were given as full as possible to practice, construct the motion, and discuss the issues. After doing the Cycle 1, the condition of the class was active enough. Actively, students did all the researcher instructions. They asked if there was any unclear instruction, asking what are the meanings of some vocabularies, how to construct the sentence, what is their job allotment exactly, etc. This strategy has built up continuously the students' activeness. But, there were still some students being passive during the process. Then, the next cycle, the researcher would more monitor the students who were not active at the class.

\section{General Conclusion for Cycle 1}

By analyzing the result of Cycle 1, which was found that 13 students failed in speaking test and some students were not active in the classroom, so the study was continued to the Cycle 2, with some modification of APD strategy implementation.

\section{Findings on Cycle 2}

Based on the result of the speaking test in Cycle 1, it indicated that the strategy of Australasian Parliamentary Debate continuously effective for improving students' speaking skill. But there were 13 students not passed the test, whereas at the preliminary study no student has passed the test. The possibilities problems of failed students were: (1) They confused how to conduct debate, because most of them recently knew the Australasian Parliamentary Debate, (2) They did not prepare well the materials what they want to argue, (3) They did not write structurally what they want to speak as the role, (4) Felt inferior.

Based on the problems above, some revisions were made to be implemented in Cycle 2. Researcher modified the planning that would be conducted in Cycle 2. The focuses of the alteration of the strategy were: 1) Teacher just gave one topic for their debate exhibition and prepared the articles toward that topic. The articles consisted of the issues of the topic, 2) For debaters, teacher prepared the more detail role of debate in a form of paper, 3) Teacher asked students to complete making outline in the first meeting of Cycle 1,4) In the second meeting, the teacher asked students to fully practice with their team to deliver what they have prepared. Then the teacher walked around and monitored directly the process of 
practice. The adjudicators were also asked to fuse the running of debaters practice, 5) Teacher asked all students to write any difficult words to be pronounced and translated. The teacher would revise at the end of the activity, 6) although some students have passed the speaking test Cycle 1, the strategy was designed to all students participating in the debate exhibition. In other words, the speaking test was for all students in Cycle 2. The passed students were asked to be adjudicators and some of them to complete the team as debaters.

\section{Students' Speaking Score}

The mean score for speaking test Cycle 2 was 85 with the highest score of 95, and the lowest score of 75 . The result had shown that the strategy has improved the students' speaking competence after applying the modified strategy at Cycle 2. All students finally got the score $\geq 70$.

In the preliminary study, the researcher found the mean score of speaking test was 43.9, after conducting the strategy by Australasian Parliamentary Debate in Cycle 1 students reached mean score up to 68, by 13 students failed the speaking test. Finally, by conducting Cycle 2, the strategy has improved all students speaking competence with mean score 85 , and $\mathrm{n}$ student got the score under 70 .

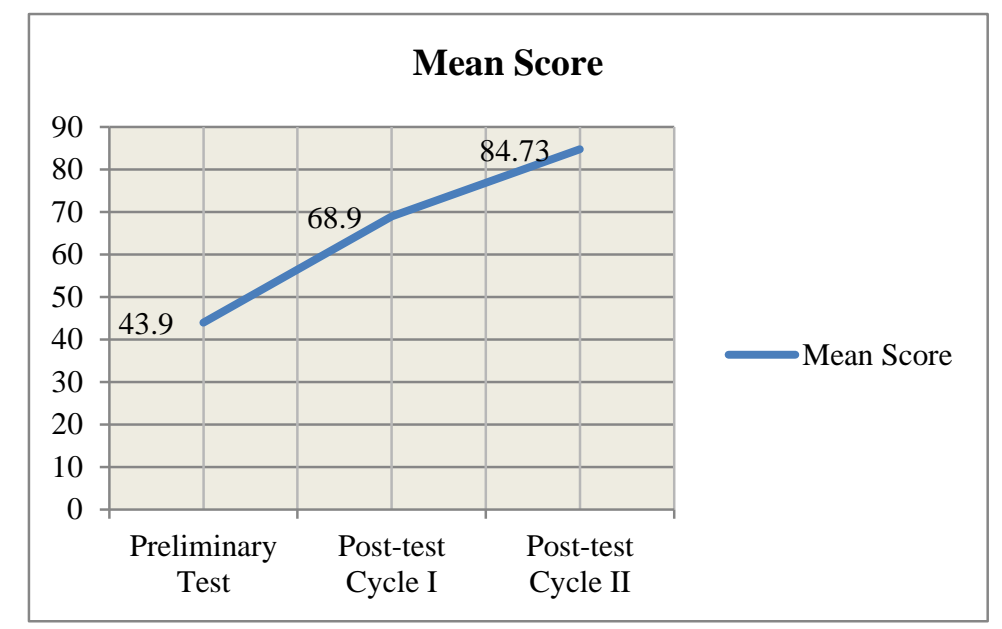

Table 1. Mean Score of Speaking Test

\section{Students' Responses}

The findings of Cycle 1 stated that students' behavior has been positively improving. They were active during the process, although some of them, about two students, were still passive at the class. The researcher more monitored students who seemed passive at the class. Directly, during they constructed the debate outline and practiced the debate, the researcher asked them what any difficulties from the teaching-learning process they got. It means that the researcher had to be active in this case. During Cycle 2, the researcher always motivated all of them especially the students who failed at the speaking test and gave a more applicable strategy that makes them did not frustrate doing debate.

They were so cooperative and more active in every activity. It made the modified strategy of Cycle 2 applied easier, and then they improved their speaking ability. It affected their performance at the final speaking test; they were confident enough to point out the arguments. Finally, their final score in the last speaking test was so satisfying.

Here, most students stated that the Australasian Parliamentary Debate was very interesting and enjoyable. Additionally, most of them were more motivated to learn speaking English. By the aforementioned discussion, the strategy was successful in term of students' responses.

\section{General Conclusion for Cycle 1}

Based on those findings in term of students' speaking score and students' responses, the researcher could reflect that the strategy was successful after doing Cycle 2. The findings have fulfilled the criteria for success. 


\section{DISCUSSION}

The discussion emphasized on how the teaching process using APD strategy can be effectively implemented for teaching speaking in the classroom. They are supported by theories and previous studies.

\section{Matter, Manner, Method}

Matter, manner, and method are the main aspects of doing the debate. The emergence of those aspects had a great contribution to make the APD strategy effectively to teach speaking. The matter is the content of the speech. It can be contrasted with the presentation style of the speech manner and the structure of the speech. Matter includes arguments, the evidence presented to support those arguments, examples, and analysis. Additionally, matter includes substantive matter and rebuttal arguments in response to the other team. A rebuttal is what distinguishes debating from public speaking. It is the point of contact between the two teams. Where there is no rebuttal, there is no engagement and there is no debate.

In speaking, students have to know what they want to speak out. They have to be trained on how to point out the content of discussion critically. Students should be introduced with global issues then analyze it to find the substantive case. Thinking critically during speaking will encourage students to improve their prior knowledge so that they have large insight as to the learner. The APD strategy trained them to prepare their matter by outlining. By caring for my instruction, the students can speak by employing their matter during debate exhibition. It helped them about what they want to argue or rebut, so no time was wasted during the debate. Furthermore, because of employing debate need to the matter, the students were encouraged to enrich their vocabularies. They would not be ably conducting the debate if they do not improve their vocabularies to outline their matter.

Then, the method is the structure and organization of the speech. The method includes the fulfilment of speaker roles, the management of speaking times, the allocation of arguments between speakers and the cohesion of the team. It also includes the capacity of the speaker to adapt their structure to respond to the dynamic issues of the debate. Speaking is not only about delivering any words or sentences but also to know how to manage the structure of the speech and responsiveness. The good speaker needs to deliver what they want to speak structurally to be understood easily by the listener. By APD, the students learned responsiveness and the structure of speaking. They recognized the job allotment and the strategy in delivering their part in a speech during debating. It effectively teaches students to always manage their speech.

Regarding how the speaker's presentation style of the speech. The students were trained in their manner. Manner includes the aspects of a speaker's presentation which contribute to or detract from their effectiveness as oral communication. Formally, students have to concern on their body language and vocal style during the speech. The variety of speaking styles is infinite. Some speakers use a forceful and authoritative style; others are quiet and calm in their presentation. Some used theatrical gestures and stride about the stage; while others are relatively reserved in their presentation. Some speakers were rapid in their delivery; others spoke slowly and deliberately. Some speakers used notes while others speak without them (Petukhova, Malchanau, \& Bunt, 2016). These elements may add or detract from a speaker's performance. There was no rule that speaking loudly is better or worse than speaking softly, or that avoiding notes is better than using notes. The test was whether the aspect of the speaker's manner contributed to or detracted from their speaking performance. It proved that the manner was a great factor to take the audience's responses massively. By concerning on their matter, method and manner students were capable to improve their speaking ability.

\section{Multimodal Teaching Process}

A multimodal approach in the classroom can be a source of creativity for both teachers and students. It draws upon available visual, audio, and kinaesthetic modes and does not necessarily rely on technology. Multimodal approaches tend to do this naturally and as the research results demonstrate, the students responded favourably to multimodal input. The majority of students preferred visual stimulus or a combination of visual and text stimuli for acquiring new lexis and for enhancing oral production (Bell, 2016; Chai \& Kong, 2017).

In the application of APD for teaching speaking in the classroom, there were some improved activities for learners. The activities were showing video of the real debate forum by PPT, reading a detailed article through surfing any information from the website, preparing the notes before doing debate, practicing debate with prepared motion, here students were allowed discussed with their opponent to build the motion, doing simulation, and reviewing the materials. In implementing APD, the researcher rested on the 3 principals of learning that stated by (Suprijono, 2009); firstly, change behavior; secondly, learning was a process; thirdly, learning is the experiences. Based on those principles, the researcher applied the strategy of APD.

To help students in understanding the rules of APD, the teacher used video as instructional media, then doing simulation. In using media, the teacher presented the video by LCD in the class. The video was the debate forum from a world debate competition in senior high school level. The video showed the debate battle of England team versus Scotland team. Maunah said that media is employed in instructional activity to facilitate teacher and students during the process of teaching and learning (Maunah, 2009). It helps the teacher to explain the instructional materials clearly and students easily 
can understand those materials. And by using a descriptive approach, introducing what APD, that was the first activity done by the researcher. The students recognized the debate, the role of debate, and how to conduct it. The students were opened minded the APD to avoiding students' confusion. Then, the researcher showed a video of the debate exhibition from the expert. By audio-visualizing the debate instruction, students more accepted the debate rules. Then, they were classified into 8 groups of debaters and adjudicators that consist of 3 students for each group.

\section{Student's Preparation}

Furthermore, the next activity done in applying APD was preparing debate outline. Outline is "line that goes around the edge of something" (Oxford Learner's Pocket Dictionary, 2011). It is about the shape or edge of something without any details. It expressed some important point about the motion. They could prepare the structural arguments that they used to deliver their arguments during debate exhibition. Students were trained to write the outline like the debate example sheet that was given for them. It trained students to speak structurally which minimize the missing understanding for the listener.

A teacher employed outline to stimulate the students' mind when delivering the arguments. But in the process of constructing the outline, some of the students still confused to arrange the arguments properly. Here, the teacher was prosecuted to be active in monitoring students' activity. Teacher accompanied students directly in outlining. The teacher would explain to who still confuse toward debate example sheet. It extremely helped students when they delivered arguments in the debate exhibition. In applying the APD strategy, distributing article was also very important to be done. It opened the students' mind what actually the case that they would discuss. Article is a piece of writing on a particular subject in a newspaper or magazine or the internet. The teacher here searched the articles on the internet. The students were asked to search more the other article relating to the motion.

By distributing the articles, teacher hoped that students were active in collecting any important information even they had to search in the other articles. This activity focused on intellectual capacity. It was considered to the students' ability to observe the data, process data, understand the information, shape the concepts, and solve the problem. The purposes are 1 Mastering inquiry methods, 2 Mastering the academic concepts and realities, and 3 Improving general intellectual skill, such as the logical reasoning prosperity (Huda, 2013).

To get beyond the limitation of a text, many EFL teachers adapt or create authentic materials and media. The articles here were one of the authentic printed materials. There are very strong reasons to use authentic materials. Authentic materials can reinforce for students the direct relation between the language classroom and the outside world. Also, authentic materials offer a way to contextualize language learning, and then students tend to focus more on content and meaning than on language. This offers students a valuable source of language input, as students can be exposed to more than just the language presented by the teacher and the text. By this activity, students more exposed their identification ability.

\section{Group Discussion}

In applying APD, absolutely students were classified into some groups, demanded to discuss the issues and gave them the opportunity to express their ideas and opinion (Khan, 2013). Here, students were trained to attract students working cooperatively with others. By applying group learning, students would work cooperatively to do the academic task into a small group then help each other and work together whether with their group or the other group(Hameed, Khalid, Aslam, Ahmad, \& Wattoo, 2013).

Moreover, by applying small group discussion to students could improve the students' intellectual and personal which cannot be achieved easily in the standard lecture situation. Because a small group was a more personal situation, it provided opportunities for interaction between teacher and students and among students. Additionally, it could help students to achieve a sense of independence and responsibility for their learning.

By giving the problematic topic that had to be discussed by students, it was based on the problem-based learning which teaches students to learn through the process of understanding the exactly cases of that problem (B Boholano, 2017). By applying this activity, students were purposed to be able some competence like Huda said (Huda, 2013) (a) Examining the case carefully, (b) Pointing out the arguments, (c) Applying their prior knowledge, (d) Merging the ideas, (e) Making decision, (f) Organizing the ideas, ( g) Making the relationships, (h) Connecting the interaction areas, (i) Appreciating culture. The activity has achieved that competence.

\section{Teacher's Rules}

Lastly, the activity done to teach the students by APD was reviewing the materials. The purpose is to consider the activities to make changes to it, changing into the correct one. The reviewing activity was done at the end of meetings. It was more common to call as the process of reflection. An effective teacher should have reflective skill. Based on the students' problem mostly in grammar, vocabularies, and pronunciation, the teacher asked students to write down first what any difficulties whether grammar, vocabularies, and pronunciation. By reviewing, students finally knew and reminded the 
correct one of their difficulties. It was the purpose that they did not have the same difficulties for next meeting and continuously. This activity helps practical problems and also developed students' prior knowledge (Chai \& Kong, 2017; Cummings \& Blatherwick, 2017; Darling-Hammond, 2006).

During applying the strategy, the teacher was also motivating students to not underestimate their ability, give them the chance to learn the language because of a desire and enjoy the activity with satisfactory experience. Although the first response, they were scarred by the term of debate, the teacher tried to persuade students that everyone was possible doing the debate. The teacher also persuaded them to believe with their own ability and asked them to open-minded. Here, the researcher also promised that the best students will get appreciation. Motivating students were the key way to omit the students' anxiety and felt unable to do the debate (Alizadeh, 2016). The teacher was surprised after getting the teachinglearning process. They were so cooperative in doing any activities. It was likely the effect of motivation. The motivation was successful

\section{IMPLICATIONS}

Finally, the study is a kind of teacher's reflection in applying the APD strategy in teaching speaking can be the reference for other teachers to apply this effective strategy in their classroom. Moreover, the study can be developed by the next researcher to probably apply the other style of debate. So, it can enrich the literature of teaching strategy that can be implemented to make the process of teaching-learning being successful.

\section{CONCLUSION}

Teaching English in digital era needs an appropriate formula of strategy that can be effectively applied in the classroom to enhance the students' communicative competence, including speaking competence. When the teaching process does not use the appropriate strategy, the students will meet the barriers to achieving the instructional goals. Based on the preliminary study conducted to the second grade of Islamic Senior High School of Blitar, the researcher found some students' speaking problems. Therefore, the Australasian Parliamentary Debate was proposed as a strategy to overcome those problems by conducting Classroom Action Research. After implementing the strategy of Australasian Parliamentary Debate in multimodal teaching-learning process, the study needed two cycles to overcome the students' speaking problems and improve the students' speaking skill. The procedure of successful APD strategy was (1) Assuring the students' understanding toward the materials that would be given, (2) Simulating, (3) Making group, classifying who became debaters and adjudicators, (4) Giving the debate motions to the students and asking them to surf any materials, (5) Making the debate battle list, (6) Discussing the motions, 7) Making an group's outline, (8) Exhibiting; the role of APD Exhibition in the classroom were: (a) Teacher opened the debate exhibition, (b) Speech was preceded by 1st speaker of affirmative, continued by 1 st speaker of negative, then rebutted by 2 nd speaker of affirmative, then 2nd speaker of negative, added by 3rd speaker of affirmative, lastly, 3rd speaker of negative, (c) Here is no replier, (d) Teacher observed and monitored the running of debate and noted any important information regarding the process of learning, (e) Teacher offered adjudicators to adjudicate the debaters' performance, (9) Evaluating, (10) Giving the constructive feedback, (11) Speaking Final Test

The researcher would like to state several suggestions for several parties such as English Teacher and the next researcher who would like to conduct a similar study. For English teacher, it is suggested that the strategy of the Australian Parliamentary Debate was need a little bit more time to make that strategy can improve the students' speaking competence. Thus, the teachers who want to apply this strategy should consider the number of students to be able to estimate the duration for students' speech. Besides, consider the number of students. It could be that the number of groups is different, so the teacher should set as effective as possible, how many students will be debaters or adjudicators, or the teachers may set all students to become the debater by their more effective way. Then, for the next researcher, the strategy which was chosen by the researcher in this study was Australasian Parliamentary Debate. There are other kinds of parliamentary debate that could be tried to be implemented as the strategy. The next researcher can explore more strategies of parliamentary debate by conducting different design, subjects, and setting. Then the result can be contrasted with this study's result.

\section{BIBLIOGRAPHY}

Alasmari, A., \& Salahuddin Ahmed, S. (2012). Using Debate in EFL Classes. Journal of English Language Teaching, 6(1), p147. https://doi.org/10.5539/elt.v6n1p147

Alizadeh, M. (2016). The Impact of Motivation on English Language Learning. International Journal of Research in English Education, 1(1), 5.

Arung, F. (2016). Improving the Students' Speaking Skill through Debate Technique. Journal of English Education, 1(1), 8.

B Boholano, H. (2017). Smart Social Networking: $21^{\text {st }}$ Century Teaching and Learning Skills. Journal of Research in Pedagogy, 7(1), 21-29. https://doi.org/10.17810/2015.45

Bell, D. V. J. (2016). Twenty-first Century Education: Transformative Education for Sustainability and Responsible Citizenship. Journal of Teacher Education for Sustainability, 18(1), 48-56. https://doi.org/10.1515/jtes-2016-0004 
Chai, C. S., \& Kong, S.-C. (2017). Professional Learning for $21^{\text {st }}$ Century Education. Journal of Computers in Education, 4(1), 1-4. https://doi.org/10.1007/s40692-016-0069-y

Cummings, J. B., \& Blatherwick, M. L. (Eds.). (2017). Creative Dimensions of Teaching and Learning in the 21 st Century. https://doi.org/10.1007/978-94-6351-047-9

Darling-Hammond, L. (2006). Constructing $21^{\text {st }}$-Century Teacher Education. Journal of Teacher Education, 57(3), $300-314$. https://doi.org/10.1177/0022487105285962

Fikri, Y. (2013). The Effectiveness of Debate in the Speaking class of Third Students of English Letters Department at IAIN Sunan Ampel Surabaya (Unpublished Thesis). State University of Malang, Malang.

Freeley, A. J., \& Steinberg, D. L. (2009). Argumentation and Debate: Critical Thinking for Reasoned Decision Making (12th ed.). Boston: Wadsworth Cengage Learning.

Hameed, S., Khalid, T., Aslam, S., Ahmad, M., \& Wattoo, F. (2013). Small Group Discussion- Impact on Student`S Test Scores in an Undergraduate Pathology Course. JUMDC, 4(1), 5.

Hans, M. E. (2017). Classroom Management is Prerequisite for Effective Teaching Dr. Anjali Hans. 6(2), 11.

Huda, M. (2013). Model-model Pengajaran dan Pembelajaran: Isu-isu Metodis dan Paradigmatis. Yogyakarta: Pustaka Belajar.

Jahbel, K. (2017). Factors affecting students' speaking performance at High Schools in Malang. International Journal of English and Education, 6(3), 15.

Maunah, B. (2009). Landasan Pendidikan. Yogyakarta: Teras.

Oxford Learner's Pocket Dictionary (4th ed.). (2011). Oxford: Oxford University Press.

Park, C., Kier, C., \& Jugdev, K. (2011). Park, C., Kier C., \& Jugdev, K. 2011. Debate as a Teaching Strategy in Online Education: A Case Study. . 37(7). Canadian Journal of Learning and Technology, 37(3).

Petukhova, V., Malchanau, A., \& Bunt, H. (2016). Modelling Argumentative Behaviour in Parliamentary Debates: Data Collection, Analysis and Test Case. In M. Baldoni, C. Baroglio, F. Bex, F. Grasso, N. Green, M.-R. Namazi-Rad, ... M. T. Suarez (Eds.), Principles and Practice of Multi-Agent Systems, 9935, 26-46. https://doi.org/10.1007/978-3-31946218-9_3

Sueb. (2014). Critical Thinking Reflected in Academic Debate Practices for English language Classroom (Unpublished Thesis). State University of Malang, Malang.

Suhendra, E. (2015). The Effect of the British Parliamentary Debate System on Students' Critical Thinking Ability (Unpublished Thesis.). State University of Malang, Malang.

Sukardi. (2013). Metode Penelitian Pendidikan Tindakan Kelas Implementasthe researcherdan Pengembangannya. Jakarta: PT Bumi Aksara.

Sulistyo, G. H. (2018). Assessment at School: An Introduction to Its Basic Concepts and Principles. Malang: CV Bintang Sejahtera.

Suprijono, A. (2009). Cooperative Learning: Teori dan Aplikasi PIKEM. Yogyakarta: Pustaka Belajar.

Syandiamita. (2011). The Effectiveness of British Parliamentary Debate System on Students' Critical Thinking Ability. (Postgraduate Thesis). State University of Malang., Malang.

Zare, P., \& Othman, M. (2013). Classroom Debate as a Systematic Teaching/Learning Approach. World Applied Science Journal, 28(11), 1506-1513. 